\title{
"Dextere sinistram vertere": Jesuits as Military Chaplains in the Papal Expeditionary Force to France (1569-70); Discipline, Moral Reform, and Violence
}

\author{
Gianclaudio Civale \\ Università di Milano, Italy \\ gianclaudio.civale@unimi.it
}

\begin{abstract}
In 1569 , Pius $v$ dispatched an expeditionary force to assist the royal armies in the Third War of Religion in France. This was the background against which the Jesuit Antonio Possevino, commissioned by Superior General Francisco de Borja and the militant pope himself, published Il soldato christiano, a short book that outlined a spiritual model of the disciplined soldier, far from previous heroic and aristocratic archetypes. Copies of the catechism were distributed to the officers and chaplains who accompanied the contingent. This essay aims to analyze the conditions in which the papal military intervention in France was conceived and the effects of Jesuit catechesis on the men who made up the papal army, as well as their reactions to this encroachment of "confessionalization" into the profession of arms.
\end{abstract}

\section{Keywords}

Pius v - Society of Jesus - Francisco de Borja - Antonio Possevino - Catholic chaplains - Wars of Religion - Catechisms - Battle of Moncontour - Huguenots

In the last days of March 1569, the news of the Catholic victory at the battle of Jarnac, fought between Henry of Anjou's royal troops and Huguenot forces, 
reached Rome with extraordinary speed. ${ }^{1}$ In the cities and territories of the Papal States, intensive efforts were underway to prepare an expeditionary force that the pontiff had decided to send to France. Every piece of information regarding the new war of religion, the third to take place on French soil, was received with special attention. ${ }^{2}$ Since his election in 1565 , Pius v had striven vigorously for the restoration of religious unity in France. To his visionary sensibility, it was a goal that represented just one stage in an eschatological and titanic struggle against the emissaries of Evil. It could only be achieved through the beneficial intervention of the Lord, solicited through a general purification of the faithful and their total adherence to the Church's teaching. ${ }^{3}$ The treatment for heretics, for those subverters of Divine order, could only be the penalty indicated in Deuteronomy 20, in which God condemned his enemies to total destruction. The pope seemed to refer explicitly to this passage when, communicating with Charles IX (r.156o-74) in order to congratulate him on his victory and on the death of the rebel leader, Louis de Condé (1530-69), he incited the king "to pursue and destroy all that remains of the enemy, to extirpate utterly the roots of an evil so terrible and so obstinate even unto its tiniest fibres." Since the king had in the past shown signs of being overly accommodating, the pope reminded him, rather threateningly, of the story of Saul: having violated the divine commandment to carry out the extermination of the Amalekites, he had provoked God's wrath and brought disgrace upon his house (1 Sam. 15:8-29). ${ }^{4}$

The sacralization of the war, implemented by the most energetic and uncompromising pope of the Counter-Reformation, was conveyed through the re-appropriation of a religious imagery that drew on some particularly violent Old Testament texts. The language of Pius v was saturated with such references,

1 The report of the battle by the nuncio Mirto Frangipani (Metz, March 21), in Archivum Secretum Vaticanum [hereafter Asv], Miscellanea [Misc.], Armadio [Arm.] II, 34, f. 214 ${ }^{\text {r-v }}$. Detailed description of the battle, like that of Edmond Auger, who was an eyewitness, had already reached Rome. ARsi, Gall., 82, 35 .

2 Numerous reports from different theatres of war are gathered in the avvisi collected in Biblioteca Apostolica Vaticana [hereafter BAv], Urbinati Latini [Urb. Lat.], 1040-41. For a more detailed analysis, see Gianclaudio Civale, "Non nobis Domine': Religione, disciplina e violenza nel corpo di spedizione pontificia nella Francia della terza guerra di religione," in Battaglie: L'evento, l'individuo, la memoria, ed. Alessandro Buono and Gianclaudio Civale (Palermo: Mediterranea, 2014), 141-48.

3 On Pius v's French policy, see Charles Hirschauer, La politique de saint Pie $v$ en France (1566-1572) (Paris: Boccard, 1923).

4 Letter of Pius v to Charles IX, March 28, 1569, in Franciscus Goubau, Apostolicarum Pii Quinti Pont. Max. epistolarum libri quinque (Antwerp: Plantin-Moretus, 1640), 3:151-53. 
his letters addressed to earthly authorities echoing with vibrant reminders of Elijah, Jeremiah, Ezekiel and Ezra. The pontiff, who was no stranger to the current of prophetic millenarianism permeating the Dominican order, ${ }^{5}$ often thundered out like a prophet, warning monarchs and prelates not to close their eyes to the proliferation of the heretical plague. However, the mandate to defend the faith and the church, to exercise divine justice, did not extend only to the Christian rulers and magistrates, but also to those, such as the captains and soldiers, who were called upon to carry it out. This resulted in a re-definition of military duty in line with scriptural example. Pius v had outlined the details of this in a letter to the Duke of Alba (1507-82) in December 1568, after the defeat of the Flemish rebels led by William of Orange (1533-84). It was an arduous undertaking to make something pious and devoted of a soldier's work, a matter of "dextere sinistram vertere" (to turn the left skil dexterously), making a heavenly enterprise from worldly labor; of sanctifying the activity of war and consecrating it to God. ${ }^{6}$ The warrior thereby could become the Lord's champion, securing to himself the eternal glory of salvation that trumped fleeting earthly honors. The Spanish condottiero was posited as the archetype for this renewed ideal of military asceticism, in which the value of Biblical exempla and the revival of crusading tensions intertwined with Counter-Reformation spirituality —a line revelatory of the influence that militant Castilian Catholicism exerted over Pope Ghislieri. Abandoning Paul IV's anti-Habsburg tendencies, he adopted the Spanish example as a model for Christian militia. The Jesuit Antonio Possevino (1533-1611) was entrusted with the task of transposing these ambitions into a concrete pastoral recommendation for the contingent commanded by Sforza Sforza, Count of Santa Fiora $(1520-75) ; 7^{7}$ the pope could then propose the product as a prototype for all Christian armies. Commissioned to write a suitable catechism for the papal soldiery, Possevino produced

5 See Enrique García Hernán, "Pio v y el mesianismo profético," Hispania sacra 45 (1993): 83-102; Nicole Lemaitre, Saint Pie v (Paris: Fayard, 1994), 42-47; 252-53.

6 Pius v to the Duke of Alba, December 12, 1568 (Goubau, Apostolicarum, 2:110-11).

7 Older brother of Ascanio, cardinal of Santa Fiora, Sforza fought under the banner of Charles V (r.1519-56) and Philip II (r.1556-98) in the Lombardy wars, in the expedition to Algiers, in the Schmalkaldic War, in the wars of Parma and Siena and, finally, in the conflict between the king of Spain and Paul IV (r.1555-59). Despite his long service for the Habsburgs, thanks to the involvement of his brothers in the French army, he was not out of favor with the Valois and the cardinal was able to ensure his command of the papal contingent. On his political maneuvering to obtain the nomination of the brother as general, see Asv, Segreteria di Stato, Cardinali, 3 . 
a short treatise entitled Il soldato christiano (The Christian soldier), which came out during the last months of $1569 .^{8}$

Since Natalie Davis's ground-breaking essay on The Rites of Violence, and Denis Crouzet's subsequent extensive contributions, research into the role played by preaching in triggering sectarian violence has become well-established, ${ }^{9}$ and many of the more interesting studies on religious conflicts have since focused on this complex relationship. Comparing French and Flemish disturbances, Pollman has showed that violence among the faithful was not the inevitable result of Catholic-Protestant confrontation, and that conflict was often determined by the type of message conveyed by church authorities. ${ }^{10}$ Tulchin has highlighted the "political" nature of sectarian violence and the leading role played by the military in certain French massacres. ${ }^{11}$ Benedict, finally, has studied the influence of Huguenot ministers on the political and military conduct of the wars of religion. The use of the scriptures, and especially the Old Testament, as sources from which to draw pointers to political action, led Benedict to theorize a form of "prophetic politics" to better understand the motivations and choices of the French Reformed church. ${ }^{12}$ It is a line of study that, if not applied too mechanically, may also be useful in interpreting the decisions of Pius v.

In a framework of general revival of studies on the role played by religion in the disciplinary process within the armies in early modern age, in recent years the papal military intervention in the Third War of Religion has attracted

Antonio Possevino, Il soldato christiano con linstrutione dei capi dello esercito cattolico (Rome: Dorici, 1569). For an analysis of this work, see Vincenzo Lavenia, "Non arma tractare sed animas': Cappellani cattolici, soldati e catechesi di guerra in età moderna," Annali di storia dell'esegesi 26 (2009): 47-100.

9 Natalie Zemon Davis, "The Rites of Violence: Religious Riot in Sixteenth-Century France," Past and Present 59 (1973): 51-91; Denis Crouzet, Les guerriers de Dieu: La violence au temps des troubles de religion (vers 1525 - vers 1610), 2 vols. (Seyssel: Champ Vallon, 1990); Crouzet, Dieu en ses royaumes: Une histoire des guerres de religion (Seyssel: Champ Vallon, 2008).

10 Judith Pollmann, "Countering the Reformation in France and the Netherlands: Clerical Leadership and Catholic Violence 1560-1585," Past and Present 190 (2006): 83-120.

11 Allan A. Tulchin, That Men Would Praise the Lord: The Triumph of Protestantism in Nîmes, 1530-1570 (Oxford: Oxford University Press, 2010); Tulchin, "Massacres during the French Wars of Religion," in Ritual and Violence: Natalie Zemon Davis and Early Modern France, ed. Graham Murdock et al. (Oxford: Oxford University Press, 2012): 100-26.

12 Philip Benedict, "Religion and Politics in the European Struggle for Stability, 1500-1700," in Early Modern Europe: From Crisis to Stability, ed. Philip Benedict and Myron P. Gutmann (Newark: University of Delaware Press, 2005), 120-38. More nuanced, the author re-proposes his interpretation in Benedict, "Prophets in Arms? Ministers in War, Ministers on War: France 1562-1574," in Ritual and Violence, 163-96. 
particular attention. Brunelli, Zwierlein and, lately, Boltanski have all investigated the episode, linking it to the development of a new international image of the papacy during the reign of Pius v. ${ }^{13}$ In this context, Il soldato christiano can be seen as the first and most important sign of the emergence of "an ambitious project of religious culture and policy."14 Possevino's writing in fact outlined an ideal model of a soldier of the Faith, one which moved away from traditional aristocratic and knightly archetypes in terms of the fundamental role assigned to discipline and obedience in the shaping of martial and religious duties. Il soldato christiano, therefore, appears to be the forerunner of the neo-stoic miles perpetuus of Justus Lipsius (1547-1606), and a prototype of the religious literature specifically designed for the military, which proliferated throughout the early modern period, developing especially in the direction of casuistry and thus incidentally revealing the pervasiveness of the post-Tridentine strategy of control of conscience. ${ }^{15}$ However a dissociation between the gradual emergence of an ideal model - the features of which became increasingly detailed and pronounced - and the real military world, characterized by mercenarism and indiscriminate violence, was evident from the outset.

Santa Fiora's campaign is well-documented: not merely military reports and diplomatic letters survive, but also detailed testimonies of the participants in the expedition, painting a close-up picture of the real living conditions of soldiers, officers and chaplains. The aim of this essay, therefore, is to analyze the disciplinary process within the Catholic world, starting from its originally martial framework, but also to consider, in the French context, the link between religious discourse and violence from a perspective that has been rather neglected notwithstanding the prolonged debate on the matter. ${ }^{16}$ Indeed, while the religious susceptibility of crowds and the role of preaching in stirring them to tumultuous displays of brutality have been examined, the same cannot be said with regard to the soldiers in war, often seen as unreflective instruments

13 Giampiero Brunelli, Soldati del papa: Politica militare e nobiltà nello Stato della Chiesa (1560-1644) (Rome: Carocci, 2003), 11-17; Cornel Zwierlein, "Intention und Funktion, Machiavellismus und 'Konfessionalisierung': Einige Überlegungen zum militärischen Eingreifen Papst Pius' V in die französischen Religionskriege 1569," in Militär und Religiosität in der Frühen Neuzeit, ed. Michael Kaiser and Stefan Kroll (Münster: Lit, 2004), 145-66; Arianne Boltanski, "Forger le 'soldat chrétien': L'encadrement catholique des troupes pontificales et royales en France en 1568-1569," Revue historique 669 (2014): 51-85.

14 Brunelli, Soldati del papa, 11.

15 See Gerhard Oestreich's classic work, Neostoicism and the Early Modern State (Cambridge: Cambridge University Press, 1982); Lavenia, "Non arma tractare."

16 On the historiographical debate, starting with Davis's study on rites of violence, see Ritual and Violence. 
of violence. The quality of the sources also makes it possible to analyze the conditions in which the papal intervention was conceived, the effects of Jesuit catechesis on the men who made up the papal army, and their reactions to this encroachment of "confessionalization," as well as to what extent the religious message propagated by church authorities influenced the violence practiced by the warring armies.

\section{The Jesuits as Military Chaplains}

Towards the end of the 156os, some notable Jesuits had already distinguished themselves in the spiritual assistance of soldiers and captains, especially in the Mediterranean theater. Initially rather haphazard, this record had not only confirmed the image of the Society as an order comparable to the military world in terms of organization and discipline, but it also helped delineate a specifically Jesuit approach to pastoral action in relation to soldiers. This mission essentially began with the election of Francisco de Borja (in office 1565-72) as the third superior general of the Jesuits. He was a knight and an aristocrat who gave up worldly fame and honors to lead a life devoted to ascetic rigor and evangelical perfection, translating the Ignatian "Meditation on the Two Standards" into reality. Under his leadership and through his example, there occurred an evolution from the typically Castilian concept of the crusader, one to which the Jesuits seemed at first to adhere, to the definition of an organic catechesis for the military. This reflected all the Jesuit pastoral care in relation to those who, even while involved in killing, carried out a meritorious action and had be on guard against any danger to the soul rather than to the body. ${ }^{17}$ The appearance of Il soldato christiano seems, therefore, to be a point of arrival, the codification of an attentiveness towards the religious status of the soldiery, which combined the magisterium of Pius v, the missionary zeal of the Society, and the pervasiveness of Tridentine strategy of control.

When Possevino returned temporarily to Rome from Avignon, he was appointed by Borja, at the express wish of the pope, to draft a religious manual for the papal troops..$^{18}$ It was a task he was able to carry out by bringing to bear all his past experience in the field. In 156o, when he was still a novice, he had

17 On the first Jesuit missions within the armies, see Gianclaudio Civale, "La Compagnia di Gesù, la guerra e l'immagine del soldato da Ignazio a Possevino (1546-1569)," Società e storia 140 (2013): 283-317.

18 ARsi, Opp. NN. 337, Possevini annales decas I, books I-IX, f. 53 ${ }^{\text {r-v }}$. In February 1569, Possevino had gone to Rome to finalize his affiliation to the Society. 
witnessed the unpreparedness and disarray of Savoyard troops as they engaged in a vain attempt to repress the Waldensians, who were constantly urged on by their ministers. ${ }^{19}$ Later in France, after the Peace of Amboise, he was also able to observe the unusual career of Edmond Auger (1530-91), the French Jesuit who became spiritual adviser to Henry of Anjou. With his work, Le pedagogue d'armes, Auger even succeeded in inspiring the drafting of new regulations for the French army, which were issued on the eve of the Third War of Religion. ${ }^{20}$

In his work, echoing the words addressed by the pope to Alba, Possevino clearly stated that the soldier at war "puts first not his own interest but rather the simple glory of God and the universal good of the Republic, and in so doing he covers himself with Honor and renders himself worthy of every great reward." ${ }^{21} \mathrm{He}$ reclaimed Old Testament examples and connected them to a vision - the principal reference being the Exercises — of Christ as the supreme condottiero, as the "Captain of Christian soldiers victoriously shedding blood." Possevino depicted for the soldiers an austere and vengeful kind of faith in the name of the wrongs suffered by the Lord: like new crusaders, they choose to devote themselves to God's cause. In doing so, he made ample use of the Laus novae militiae, written by Bernard of Clairvaux (1090-153) in praise of the Knights Templar. He took from the Cistercian saint's work the traditional themes: the death of the Christian soldier as a sacrificial act and the extermination of heretics and infidels as malicidium not to be regarded as a sin but as a praiseworthy action. ${ }^{22}$ This heroic conception, however, was encased within a rigid scheme that held up moral rigor and martial discipline as its most distinctive qualities. The teaching provided by the Baptist as a singular way of salvation for soldiers ("Do violence to no man, neither accuse any falsely; and be content with your wages," Luke 3:14) was developed in a detailed list of recommendations intended to make clear the requirements of the perfect Christian militia. In an enterprise blessed by God, the general should not only be courageous and wise, but also devoted and expert "in matters of faith." In the

19 On the Waldensian resistance, see Gianclaudio Civale, "Da martiri a combattenti per la fede: La guerra delle valli e le dinamiche della militanza riformata valdese (1555-1561)," in Predicazione, eserciti e violenza nell'Europa delle guerre di religione (1560-1715), ed. Gianclaudio Civale (Turin: Claudiana, 2014), 157-82.

20 See Austin Lynn Martin, Henry III and the Jesuit Politicians (Geneva: Droz, 1973); Gianclaudio Civale, "Religione e mestiere delle armi nella Francia dei primi torbidi religiosi: Il 'pedagogue d'armes' del gesuita Emond Auger (1568)," Bibliothèque d'Humanisme et Renaissance 74 (2012): 505-33.

21 Possevino, Il soldato christiano, 8. Possevino himself indicates Alba as a prototype of "Christian captain" (Possevino, Il soldato christiano, 72-73).

22 Ibid., 12. 
conduct of the campaign, he must "carry God before his eyes" and, therefore, be careful to choose only experienced soldiers: those motivated, not by lust for glory and riches, but by the nobility of the cause. ${ }^{23}$

The "holiness" of the soldiers' mission was designed to break down the solidarity typical of men at arms, in order to establish an uncrossable line between the Christian militia and the faithless and heretical mob, with whom there should be no contact: in Possevino's view, "You cannot have to do with pitch and not be soiled" (Sirach 13:1). ${ }^{24}$ The Christian soldier had to stay away "from heretics and their books"; to banish blasphemy, drunkenness, theft, vainglory, lust and gluttony; and behave pacifically towards his fellow soldiers, avoiding duels and jousts. However he did have to practice his skills and to keep his weapons always in an orderly state. ${ }^{25}$ In place of sinful occupations, soldiers in repose would dedicate themselves to prayer and the reading of uplifting stories drawn from the Scriptures, devotional literature and the classics. ${ }^{26} \mathrm{~A}$ key role, therefore, would be occupied by "preachers in the field, because every company would have its priest to assist and serve in matters of the spirit."27 "Prayer with tears, with fasting, with the most holy sacrifice of the Mass, with the sacraments and with preaching," would endow "the soldiers with greater force" because "it must be known that there is no virtue equal to that of prayer." ${ }^{28} \mathrm{To}$ enhance the "virtue" and "fortitude" of the Catholic militias, Possevino proposed a "sequence of prayers [...] that the soldier must say," which reflected the intention to "sanctify" the daily life of the military. ${ }^{29}$

An immediate practical achievement of Possevino's pamphlet is revealed in the inclusion of his provisions in the instructions issued to the commanders of the expedition and to the religious figures who would be accompanying them. Santa Fiora was reminded that the task had been bestowed upon him because it is right to choose a leader "no less a good Christian and true Catholic, and attentive to the proper discipline of his men, than one [...] valiant" in battle. In addition, he was advised

to attempt with all study to introduce into these men the true fear of God, without which it can never be hoped to do good, eradicating above all the

\begin{tabular}{ll}
\hline 23 & Ibid., 17-28. \\
24 & Ibid., 29-34. \\
25 & Ibid., 35-52. \\
26 & Ibid., 57-58. \\
27 & Ibid., 17. \\
28 & Ibid., 23. \\
29 & Ibid., 77-78.
\end{tabular}


execrable vices of blasphemy and gambling, the cause of many evils and great disorder, and all other vices, repressing military licentiousness [...], binding the soldiers one to the other and maintaining their obedience, so that in such a way all places that they pass through and all the kingdom of France may clearly see that good Christians soldiers are sent here, and true Catholics, to defend them from the impiety [...], and not dissolute and rapacious men to plunder them, and this you are charged by His Holiness to do with all possible ardor. ${ }^{30}$

Religious discipline was adopted as the only antidote to "military licentiousness": the example of these "true Catholics" would function as a tool of propaganda in order to stem the spread of heresy. The importance assigned to the military expedition was reaffirmed in the orders issued to the bishop of Fermo, Lorenzo Lenzi (1516-71), the army's commissioner and treasurer. ${ }^{31}$ His responsibilities should have been limited to the management of logistic and the supervision of payments; ${ }^{32}$ but the pope was keen to give him wider powers, involving a vicarial role that included both pastoral functions and spiritual policing. His task, in fact, was to ensure "that these men would serve as an example in religion, obedience and discipline for the wretched." To this end, he was required to take "special care for the avoidance of commerce and of sinning through colloquy and dispute with heretics." Finally, no one of any degree or condition should possess suspicious or prohibited books or writings: "in this you are commanded by His Holiness to employ the utmost diligence [...] with the most rigorous interdictions and penalties." ${ }^{33}$ This plan of inquisitorial surveillance was inserted within a system of indulgences that reflected the revival of the traditional crusader spirit. In fact, with a brief of March 10, 1569, the pope gave to Lenci special powers to absolve from all sins "etiam Sedi Apostolicae reservatis" and accord the soldiers "plenary indulgence in articulo

30 "Istruttione al conte di S.ta Fiore generale delle genti mandati da Pio V in Francia," Rome, March 9, 1569. ASv, Fondo Pio 112, ff. $20^{\mathrm{r}}-24^{\mathrm{v}}$. See a copy in BAv, Barb. Lat., 5040, ff. $77^{\mathrm{v}}-80^{\mathrm{r}}$. Lenzi was a favorite of Catherine and Cosimo de' Medici (r.1537-69) and, like Pope Ghislieri, he had benefited from the patronage of Paul IV. He had spent many years in France as papal delegate and as vice-legate at Avignon, where he had distinguished himself in the repression of the Huguenots. Stefano Simoncini, "Lenzi, Lorenzo," in Dizionario biografico degli italiani, vol. 64 (http://www.treccani.it/enciclopedia/lorenzo-lenzi _(Dizionario-Biografico), accessed May 2, 2017).

32 Gianpiero Brunelli, "I commissari generali dell'esercito pontificio tra Cinque e Seicento," Dimensioni e problemi della ricerca storica 2 (2004): 175-206.

33 "Istruttioni al vescovo di Fermo commissario delle genti mandati da Pio V in Francia," Rome, March 9, 1569 (ASv, Fondo Pio 112, ff. $28^{\mathrm{r}}-3^{2}$ ). 
mortis." ${ }^{34}$ The delegated exercise of these prerogatives was the task of the military chaplains assigned to the army. ${ }^{35}$

Thus, by order of the pope, Borja selected five Jesuits from amongst the staff of the colleges of Perugia, Macerata, and Loreto: the areas where the recruitment of the soldiers generally took place. Their duties were to run the infirmary and to ensure the spiritual discipline of the soldiers. Appointed head of the mission, the rector of the college of Perugia, Curzio Amodei, received a series of instructions, which stated that

the main purpose of this mission is to ensure that the Italian soldiery sent by His Holiness goes about its business with true Christianity because thus it may be hoped that God will receive the greater assistance [...] to establish true religion and pacify the Kingdom of France.

The Jesuits were to set an example of Christian life, demonstrating "love and modesty" and to teach soldiers to "hold high intention [...] in this endeavor." At stake, indeed, were "the honor of God, and the increase and exaltation of the holy Catholic faith, and the common good." With sermons, daily masses, "litanies, Salve regina, and other prayers," they would attempt to "persuade them that the more they were virtuous and in the grace of God, the more courageous and valiant would they be." In so doing, "God's protection would be drawn to them and so greater success would be given to their endeavors." In sermons, but also in more informal moments of catechesis, the Jesuits were to urge them to "withdraw from those sins that were wont to be familiar to this kind of men," helping to prevent the rise of any "enmity" for "honor and personal interest." Finally, the priests should be dedicated to administering the sacrament of penance and letting it be known they were available to hear the soldiers' confessions "both day and night" - rather briskly, however, so that, with battle near, they might purify as many people as possible with absolution. ${ }^{36}$ The piety of the soldiers was to be stimulated through the distribution of Il soldato christiano, printed in convenient octavo copies for ease of use, and other devotional

34 ASV, Segreteria Brevi, Registri 12, 101.

35 To maintain the group of Jesuits, Amodei was paid fifty scudi a month, a far from negligible figure. The same amount was paid to the sergeant major of the army, Saporoso Matteucci (1515-78). To compare, the mestre de camp earned one hundred scudi, the bishop of Fermo, three hundred, and the general, five hundred. ASv, Archivum Arcis, Arm. I-XVIII, 3952, s.f.

36 "Instruttione per quelli che si mandano in Francia col campo del papa," ARsi, Inst. 117a, ff. $290^{\mathrm{r}}-291^{\mathrm{v}}$. 
works, as well as the gift of "rosaries or prayer books." In Jesuit strategy, the army seemed to offer a fresh new terrain for their mission, for the spiritual instruction and transformation of that particular category of the faithful. The unusual path to salvation available to soldiers, however, requiring the presence of priests, seemed to involve, at least in the Catholic version, a certain degree of "clericalization" of the army. As for other human occupations, ecclesiastical control was both a symptom and a product of the model engendered by an orderly and religiously directed society.

\section{Jesuits and Devotion in the Papal Army}

Amodei's regular letters, along with the diary of the French campaign kept in the Vatican Library, ${ }^{37}$ represent sources of great value not only for studying an army from within, but also because they offer an opportunity to verify the practical effects of the religious and ideological initiative sponsored by Pius v. From April 1569, the troops began to arrive in the plain of Volpiano, a few leagues from Turin. The Jesuits joined them there at the beginning of May. At the suggestion of Santa Fiora, they waited a few days to begin their ministries, until the companies had received their money. This seemed a wise move, and Amodei reported with satisfaction that "we waited to take confession as the soldiers were paid and by the grace of the Lord we did not lack work to do and confessed many, and many more would have been confessed if they had not been prevented by inspections."

At this early stage, the atmosphere in the camp was a very orderly one. Inspection was the occasion to promulgate some prohibitions regarding gambling and blasphemy, but even before this, Amodei reported that "the soldiers are as well-behaved with each other as one could wish, and even before they were paid and no prohibition was established they were not heard to blaspheme." ${ }^{38}$ The soldiers' contentment was also reflected in their attitude towards the Jesuits: "we have an excellent crowd, and [...] it seems that we have always known one another and that we belong all to the same profession." He

\footnotetext{
37 "Narratione della Guerra di Francia seguita l'anno 1569. Dove [...] Santa Fiora fu capitano generale della gente italiana mandata da N.S.r Pio v," BAv, Barb. Lat. 5040, ff. $76^{\mathrm{r}}-18 \mathbf{1}^{\mathrm{v}}$. Zwierlein attributes the manuscript to Rovio Belmonte, secretary of the general. With almost daily annotations, it covers a time span ranging from May 6 to December 1569 , describing the journey made by the main part of the contingent, from its first assembly in the Canavese region to its disbanding in Susa, seven months later.

38 Amodei to Borja, Volpiano, May 5 and 10, 1569. ARsi, Gall. 82, ff. 59-6o.
} 
was eager to record that his brothers were kept busy "in confessing continuously from the early hours of the morning until lunchtime, and then after lunch until the evening, so I truly have the impression of being in the Holy Penitentiary [Sacra penitenzieria]." ${ }^{39}$ Therefore, auricular confession was confirmed as the cornerstone of the Jesuit spiritual program also with regard to men-at-arms. Even more than public sermons, the sacrament of penance appeared to be a flexible tool to induce the required change of behavior that would create a more authentic Christian military service.

The soldiers, as Santa Fiora indicated, seemed to be prone to unexpected demonstrations of obedience and devotion, as long as they were satiated and content. This cheerful state of mind would last until the troops made their way into the war zone. From Lyon, where they received a festive welcome, Amodei wrote that the soldiers acted "very modestly, so that those of the city $[. .$.$] were$ full of admiration for their behavior, knowing them neither to blaspheme nor indulge in gambling [...], and I think that it will be written to His Holiness of the good odor they will leave of themselves." Abstention from gambling and blasphemy was seen as the main symptom of success of the Jesuit mission in terms of a moral reform of the army. An exemplary anti-heretical effect was also envisaged. The confidence of the Jesuits, however, was questioned by those who, more experienced in such matters, were aware that, as the campaign progressed, the soldiers "would go to ruin through the bad example of others." Such concerns about maintaining discipline amongst the troops were destined to become a reality. Just twenty days later, in Limousin, Amodei was forced to confirm to his superiors that, due to difficulties with provisioning, "things with our soldiers have gone very badly, because on the road they have done little else but thieve and do harm." ${ }^{41}$ From Lyon, the expedition had proceeded by forced marches through a region that had already experienced the passage of the royal armies and the Huguenot troops: there was little left. Afflicted by shortage of food, despite the risk of draconian punishment from the officers, the soldiers tended to leave the road to wander through the countryside and extort whatever they needed from the local population. ${ }^{42}$ Before arriving in Lyon, Santa Fiora had hanged a soldier over a simple matter of insubordination, to demonstrate to the others that "if they will not be obedient, then they

39 Amodei to Borja, Volpiano, May 16, 1569. Arsi, Gall. 82, f. 63.

40 Amodei to Borja, Lyon, June 4, 1569. ARsI, Gall. 82, f. 70. In Lyon, the Jesuits could count on the help and advice of Auger.

41 Amodei to Borja, June 26, 1569, campo del re. ARsi, Gall. 82, f. 82.

42 ARsi, Gall. 82, f. $109^{\mathrm{v}}$. 
will be most severely punished."43 Amodei had been on hand to confess the condemned man and accompany him "to the place of justice, comforting him along the way and with a crucifix in hand, and with the Lord's grace he acted most well, and before he died pronounced some words of edification [...] and was a great example." 44 The severity of the sentence imposed by the count, who had ordered a punishment contrary "to strict military reason," seemed to be inspired by Possevino's teachings: the Jesuit, in fact, had advised the officers to be inflexible in their punishment of those responsible for "discord" in order to furnish tangible examples of authentic Christian discipline. ${ }^{45}$ Amodei's intervention had turned the execution into a religious ceremony, the goal of which, following the paradigm that underlay the brotherhood's activity on behalf of comfort for the "afflicted," was not the punishment, but the exemplary reconciliation of the convict. ${ }^{46}$

However, after this episode there was no sign of cooperation between army officers and church representatives to establish the double parametersreligious and military - of an ideal pattern of conduct. Executions, duly recorded by the campaign diary, were repeated with frequency, showing a superficial reception of the new form of behavior preached by the Jesuits. And if, in the early stages of the march, commands were issued that "every soldier is obliged to hear Mass" on the Feast of Corpus Christi, ${ }^{47}$ thereafter the count and all his officers seemed to neglect any assistance to the Jesuits. Amodei was forced to admit that "not only are we not helped in carrying out our ministry, but we are hindered." It was even decided to use a chapel that stood near the military quarters for storage and the fathers were deprived of the chance of "preaching, saying Mass, and hearing confession."48

Absorbed into a predominantly mercenary army, composed of seventeen thousand infantries and eleven thousand cavalries, ${ }^{49}$ the papal troops had to suffer, even more than previously, from scarcity of supplies. Their excesses earned them an official reprimand from the duke of Anjou, who ordered Santa

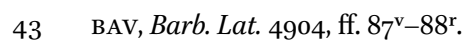

44 Amodei to Borja, Lyon, June 4, 1569. Arsi, Gall. 82, f. 70.

45 Possevino, Il soldato christiano, 38.

46 See Adriano Prosperi, Delitto e perdono: La pena di morte nell'orizzonte mentale dell'Europa cristiana, XIV-XVIII secolo (Turin: Einaudi, 2013).

47 BAV, Barb. Lat. 4904, f. $102^{\mathrm{v}}$.

48 Amodei to Borja, June 26, 1569. ARsi, Gall. 82, f. 82.

49 The most detailed study on the Third War of Religion is yet Stèphan C. Gigon's $L a$ Troisième Guerre de Religion: Jarnac-Moncontour (1568-69) (Paris: Lavauzelles, 1909). See James B. Wood, The King's Army: Warfare, Soldiers, and Society during the French Wars of Religion, 1562-1576 (Cambridge: Cambridge University Press, 1996), 16-28. 
Fiora to punish with their lives those responsible for looting and violence against the population. ${ }^{50}$ At the beginning of July, Amodei admitted that "our army proceeds very badly, both for the disorder they make and for blasphemy and gambling."51 The Christian discipline that the pope intended to be the clearest attribute of the papal army, and even the "good odor" that the soldiers had at first left behind them as they passed, seemed to have evaporated. The Jesuits, however, had no time to complain. War and hunger paved the way for another scourge: the plague. In order to cope with the increasing number of patients, the Jesuits were granted the equipment to set up a field hospital. Until their return, their correspondence with Rome became a series of laments regarding the conditions of the sick and the many dead. By the end of July, Amodei was predicting that "few Italians will return" and confessed to Borja that "if the pope knew how greatly the army suffers [...], I think by this time he would have called his soldiers home."52 At the end of August, the commanders were forced to leave the priests at Tours, where at least seven hundred sick had been hospitalized. In his instructions issued to the chaplains, Borja had explicitly told them to not "allow the sick and injured to lack for anything in the needs of the body, or of the soul"; and the priests had been urged "to confess them as soon as it is possible [...], commending their souls." ${ }^{n 3}$ The chaplains, therefore, dedicated themselves with passion to assist the dying-something which was one of the specific ministries of the Societas - and neglected their work of ministry to the soldiers in the field. In these circumstances, Lelio Sanguigno was still able to find reason to praise the Lord for the fact that the sick "are at least helped in their souls and do not lack nourishment for the spirit."54 In their efforts to aid the sick, all five members of the mission fell ill, and Sanguigno himself died.

The news of the victory at Moncontour, as triumphant as it was unexpected, arrived in Tours on October 4, when Amodei was preparing to send back $35^{\circ}$ to four hundred soldiers to Italy, all of them too sick or seriously injured to be useful for service. ${ }^{55}$ The victory gave Santa Fiora the opportunity to plead to the king of France for "authorization to return to Italy." Only when the king

50 The Duke of Anjou to Santa Fiora, Lassac, July 3, 1569. Asv, Segreteria di Stato, Cardinali 3 , 198. The count seemed to sympathize with his troops and "out of compassion he did not punish according to rigor of the law." BAV, Barb. Lat. 4904, f. $149^{\text {r }}$.

51 Amodei to Borja, Objat, July 4, 1569. ARsi, Gall. 82, f. 86.

$5^{2}$ Amodei to Borja, Pernac, July 21, 1569. ARsi, Gall. 82, f. 100.

53 ARSI, Inst. 117 a, f. $291^{\mathrm{v}}$.

54 Lelio Sanguigno to Borja, Montbazon, August 6, 1569. ARSI, Gall. 82, f. 112.

55 Amodei to Borja, Tours, October 8, 1569. ARsi, Gall. 82, f. 160. 
reached the walls of Saint-Jean-d'Angely and was able to see for himself the seriousness of the situation, did he grant leave to the Italian troops. The journey home was afflicted by the "great sickness that was generally in all the people." Santa Fiora himself fell ill and had to abandon his leadership of the contingent, preceded by many other officers who had preferred to hasten back to Italy in advance. Left to itself, the army, "exhausted and distressed, took itself where best it could." ${ }^{56}$ In Lyon, orders came from Rome that the army should turn back to Avignon; but many soldiers, scattered as they were, were taking to the road to Savoy. They did not even wait for payment, for "so many of them were weary of being held back by those groups among whom nothing was to be seen but sickness and death." 57

\section{Religious Violence?}

Santa Fiora expressed his strong opposition to the injunctions of Pius v that postponed the return of his men to Italy. ${ }^{58}$ Demoralized and offended by what he considered an intrusion into his sphere of command, he chose to retire to his own estates, without passing through Rome at all. Thus, the expedition ended in inglorious dissolution, while at the papal court Santa Fiora's act of insubordination brought only disgrace to his name. It was based on the impossibility of continuing the campaign that had lost almost all its military strength. While the sources do not make it realistic to follow the gradual diminution of the troops in detail, there is one fact that seems to suggest the scope of the contingent's disintegration: at the beginning of October, on the battlefield of Moncontour, out of the 5,400 soldiers that made up the original army, only 1,850 were fit to take the field. ${ }^{59}$ The rest were dead, or lay sick or wounded, or had abandoned their units. In general, foreign contingents were less prone to desertion en masse, mainly because of the difficulties of being able to return home. This was something that can only have partially affected the Italian army. Amodei himself seemed to share the sense of disillusionment that pervaded the troops when, from Turin, he wrote to his superiors of the "great danger of going to Avignon," and the risk of prolonging a grueling experience he had survived only thanks to the refusal of the soldiers and to their "morose

$5^{6}$ An avviso from Lyon refers to the arrival of "vestiges of the Italians [...], utterly spent and enfeebled, and no more in the form of men." December 4, BAV, Urb. Lat. 1041-I, f. 194".

$5^{8}$ Ibid., f. $175^{\mathrm{r}-\mathrm{v}}$.

59 Ibid., ff. $165^{\mathrm{v}}-166^{\mathrm{r}}$. 
dissatisfaction" that had prompted the pope to desist from his purpose ${ }^{60}$ It is possible, therefore, that, although far from home, various bands of soldiers had decided to desert, running the risk of encountering enemy contingents or ambushes from peasants enraged by looting.

The constant attrition which units were subject to explained the ragged fitsand-starts nature of the whole campaign from the beginning. It was dogged by halts, then featured moments of great vitality thanks to the injection of fresh reinforcements, and then further halts as they waited to join up with new attachments of troops. ${ }^{61}$ The disposition of the papal contingent followed a similar pattern. On its arrival, it revitalized the Catholic army and was deployed in some skirmishes, in the battle of Roche-l'Abeille, where victory went to the Huguenots, in relieving besieged Poitiers and in the assault on the stronghold of Châtellerault. At this point, it seemed to lose any fighting spirit. As a consequence, the royal army's activity stalled until its ranks were replenished by the arrival of new French forces.

In a conflict characterized by attrition rather than by decisive battle, the tactics that brought victory were those employed by Alba in Flanders. As Possevino himself reported, the Duke had managed to maintain offensive potential longer than his opponents. ${ }^{62}$ To achieve this, however, the soldiers needed to be supported with adequate logistics and health care and at least the promise of payment. Imposition of an iron discipline, loyalty to a cause, and faith in leadership were all factors that made it possible to overcome the privations of war. Subjected to the harsh conditions of the French Civil War, the papal army had not been up to the task: they had fallen apart as easily as a force made up of mercenaries. Pius v's dream of forming a new military crusade that, by virtue of its faith, might assist the Catholics of France and then continue its mission in Flanders, in the Comtat Venaissin, or in any other endangered region, evaporated into nothing. ${ }^{63}$

If the efforts of the Jesuit chaplains had little effect on changing the ungodly behavior of the soldiery, the question remains to what extent the pontiff's appeal for the massacre of heretics, partly derived from Possevino, influenced the papal army's actual performance in battle. The message regarding the extermination of the enemy as an act of religious purification, subversive in content,

\footnotetext{
6o Amodei to Borja, Turin, December 31, 1569. ARsi, Ital. 137, ff. 368-69.

61 See Wood, King's Army, 229-37.

62 Geoffrey Parker, The Dutch Revolt (New York: Penguin, 1984, $2^{\text {nd }}$ edition), 105-10.

63 The instructions by Pius v to Santa Fiora prescribed that, after the operations in France, the contingent would move to garrison in Avignon or to provide assistance against the Flemish rebels. Asv, Fondo Pio $112, \mathrm{ff}^{2} \mathrm{O}^{\mathrm{r}}-24^{\mathrm{v}}$.
} 
could benefit from the sanction of officialdom within a military context where obedience was one of the principal values. It seems to explain the central role played by soldiers and "paramilitary" combatants, such as the militias, in carrying out most of the massacres that took place during the French Wars. ${ }^{64}$ The violence inflicted by the papal forces upon the population was predominantly predatory in nature, taking the form of plunder rather than the actual elimination of civilians. Moreover, sources do not depict the latter in terms of any particular religious shading. Nevertheless, it still remains to be clarified to what extent military conflict was subject to the "sacralization of war" put forward in speeches and at a ritual level.

In the battle at Roche-l'Abeille, on June 25, the papal force was called back hastily into the field. They maintained their positions but did not support the advance of the French infantry, thus allowing the semi-encirclement and capture of the mestre de camp, Filippo Strozzi. The Italians offered a better account of themselves on September 7 , under the walls of Châtellerault. Leading the first wave of the assault to a breach, however, they were repelled with heavy losses by defenders who were emboldened at facing the soldiers of the pope. ${ }^{65}$ On both occasions, the Jesuits were to the rear, with no way either to hear confession or to deliver sermons before the fight. Their function, it appears, was restricted to looking after the wounded and dying, to the reaffirmation of the salvific value of confession, especially for those who needed, on their deathbeds, to be reconciled with the Lord. This is confirmed not only by their concern for the sick, but also by the speed with which, in July, near Pernac, Amodei wanted to reach the site of a skirmish in order to provide the last sacraments and ensure the indulgence in articulo mortis for several soldiers. ${ }^{66}$

Nor were the Jesuit chaplains able to be present at other feats of arms in which the Italian troops took part. The failed Huguenot siege of Poitiers, between late July and September, constituted a turning point in the entire campaign. Recognizing the strategic importance of the city, the Catholic leaders had been transferring since August numerous troops to the forces of Henri de Guise. These included four hundred harquebusiers and two hundred Italian cavalries under the command of Paolo Sforza. The citadel provides us with a privileged place to observe the cohesive power of religion, its language, its depictions and its results. ${ }^{67}$ The siege also represents an extreme situation from

64 See Tulchin, Massacres, 100-26.

65 BAV, Barb. Lat. 4904, f. $153^{\text {rvv }}$.

66 Amodei from Pernac, July 21, 1569. ARsi, Gall. 82, f.10o.

67 For the siege and its religious implications, see Cornel Zwierlein, "Fame, violenza e religione politicizzata: Gli assedi nelle guerre confessionali," in Militari e società civile 
a religious point of view, with the barrier between the two faiths becoming a palpable reality, embodied in the walls that separated the besieged from the besiegers. For the authorities of the city, its defense was not just a matter of survival and protection; it took on a transcendental sense: the superiority of their faith over that of the opposing army. The symbols of religion became treasures to preserve, even to the point of martyrdom: and above all, they were icons from which fresh vigor could be drawn to sustain the struggle against the enemy.

The chronicle of the siege published by Marin Liberge (1537-99) in 1572 registers a climate of great religious tension, and cites many incidents where the defenders offered evidence of their devotion. Several of these also involved the papal troops. The author recalls how, after the pontifical forces had successfully defended a breach, Paolo Sforza, brother of Santa Fiora, wanted to offer up the still-bloodstained clothes he had worn during the engagement as a pledge of his faith. Even more indicative of the strength of religious feeling than this rather macabre votive offering was an oath pronounced by the Italians before rushing to repel yet another assault. They were harangued by an officer, who asked them rhetorically "if they were ready [...] to show what they had promised to do in all this war, namely to commit their lives to the defense of the Christian religion, the Holy See and the Most Christian King [...]. If they intended, therefore, to conduct themselves in combat, not as foreigners and Italians, but as good and true Christians." To this appeal, the soldiers answered with a form of Roman salute, "their hands to the sky," and swore before an image of Christ "to die rather than betray their duty." Then they went into the cathedral where the relics of St. Radegund were kept, and, as battle and the possibility of death beckoned, kneeling, they commended their souls to God with "prayers and humble vows." ${ }^{8}$ This unexpected show of devotion on the part of foreign soldiers who had been perceived as little more than mercenaries, with no interest in the French religious cause, aroused admiration and instilled a spirit of emulation.

It is impossible to ascertain whether such an uplifting ceremony actually took place, or if it owes more to the hyperbole of the chronicler. However, it remains the only evidence of the papal troops laying swearing to defend the faith until death, making an oath that, in Pius v's plans, was to be imperative for every Catholic army. The days preceding Moncontour, on October 6, took place

nell'Europa dell'età moderna (secoli XVI-XVII), ed. Claudio Donati and Bernard Kroener (Bologna: Il Mulino, 2007), 497-545.

68 Marin Liberge, Le siège de Poitiers suivi de la bataille de Moncontour et du siège de St Jean d'Angély, ed. Henri Beauchet-Filleau (Poitiers: Letang, 1846), 81-83. 
in a climate of growing exasperation further exacerbated by fatigue, hunger, and death. The situation was a critical one, which could have also fostered the revival of chiliastic anxieties stimulated by religious figures. At Tours, while the Italian Jesuits were committed to assisting the sick, Possevino himself was on hand to play a significant role in rousing the soldiers' spirits with his sermons. He was even heard by the royal family, who had arrived to follow the campaign up close. Possevino intended his penitential homilies to "awaken the Christian choirs to do their duty here at least with tears and prayer, because all around us now nothing is understood but death and the most melancholic indifference towards the things of the Lord Our God." In an attempt to appease "the wrath of God" and invite His benevolence, the Jesuit tried to promote anti-heretical devotional practices, such as the cult of the Blessed Sacrament. Thanks to the wishes of the Cardinal of Lorraine, the Duke of Anjou also introduced the veneration of Corpus Christi into the nearby army camp. The sacramental bread was exhibited in a church in the middle of the military quarters and, during a visit from the king, was carried along a processional route to the town church of Saint Martin. Here, Possevino preached before an audience of four thousand persons. ${ }^{69}$

Despite the flurry of religious activity in the previous days, sources mention no devotional event taking place on the field of Moncontour. The Jesuits, Possevino and the bishop of Fermo, were otherwise engaged. No one was present to bless the soldiers as the time of battle grew near. Nevertheless, certain details suggest the religious nature of the conflict. In order to be able to recognize each other, the Catholic troops adopted white crosses as distinguishing features - the same crosses that had appeared for the first time at the Battle of Saint-Denis and would be worn during the St. Bartholomew's Day massacre. In addition, according to Marshal Tavannes (1555-1630), Catholics attacked with shouts of "au nom de Dieu!"70

The battle was short-lived, lasting only half an hour. ${ }^{71}$ As in several other battles in the French Wars of Religion, the two cavalries clashed with each other with no prior tactics being decided: to all intents and purposes, it was a trial by ordeal, as if only individual valor and God's favor to would decide the outcome. On the right flank, Italian squadrons fought against Huguenot cavalry and some companies of German reiters. The battle soon degenerated into

69 Possevino to Borja, Tours, September 10, 1569. ARsi, Opp. NN. 324-II, 186, 189.

70 Jean de Saulx, Mémoires de [...] Gaspard de Saulx, seigneur de Tavannes (Paris: Neufchaise, 1653), 356.

71 François de La Noue, Discours politiques et militaires, ed. Frank E. Sutcliffe (Geneva: Droz, 1967), 760-66. 
a melee between isolated groups of combatants. The decisive move was made with an advance to the center by the square of Swiss Catholics, who routed the enemy cavalry. The Huguenot infantry remained isolated, at the mercy of the Catholic horsemen and the infantry who moved up to support them. ${ }^{72}$ As the Protestant forces retreated in disarray, the conflict was transformed into a massacre. The regiment of four thousand Landsknechts in the service of the Huguenots attempted to withdraw in an orderly fashion, only to be surrounded and massacred by the Swiss. Some have attributed this particularly ferocious episode to the long-standing rivalry between two nations who were direct competitors in the mercenary market. Contemporary evidence, however, suggest a more complex reality in which military logic became intertwined with religious hatred. According to François de La Noue (1531-91) and La Popelinière (1541-1608), the Swiss were animated above all by a spirit of revenge for the defeats suffered in Roche-l'Abeille and in Béarn, where the Catholic commander had been executed. No Swiss units, however, had been present at these conflicts. The extermination of the Landsknechts, therefore, was not so much due to their role as mercenaries, but rather to the fact that they were heretics, for whom total destruction had been decreed. Many of them, in fact, in a vain attempt to save their lives, cried out "with clasped hands and knees to the earth [...], 'Bon Papiste! Bon Papiste, moy!"; but the victors were deaf to their pleas. ${ }^{73}$ The Catholics wanted to put all their enemies to the sword, including the French. The fury was both absolute and liberating: a reaction that seems to have emerged from the feelings of pollution analyzed by Davis. Only a tardy command from the Duke of Anjou put an end to the extermination. Meanwhile an unknown number of Huguenots-something between six and ten thousand men - were left on the field. Just a few gentlemen, handed over as prisoners to Catholic aristocrats, were granted their lives in exchange for the promise of a heavy ransom. On the opposing side, the losses did not exceed seven hundred men, mainly amongst the cavalry, including those of the papal forces. In the Jesuits' eyes, they had won entry to the kingdom of Heaven. Amodei himself interpreted the battle as a malicidium. Commenting on the death of an Italian gentleman from injuries sustained in combat, he wrote: "We said the Masses, and prayed to our Lord for his soul; God grant that these were

72 The first description of the battle reached Rome in an avviso from Paris, October 15, 1569. BAv, Urb. Lat. 1041-I, ff. $168^{\mathrm{r}}-169^{\mathrm{v}}$.

73 Henri Lancelot Voisin de Popelinière, La vraye et entière histoire des trouble et choses mémorables, avenues tant en France qu'en Flandres [...] depuis l'an 1562 (Geneva: Davantes, 1573), f. $183^{\mathrm{v}}$. 
accepted, even though I trust that there will be little need for them, for one who died for the faith in so just and honorable war." ${ }^{\prime 4}$

In a context where celestial design intersected with worldly reality, the credit for the victory was attributed entirely to the Lord and to the wonders that He performed for his followers. Suffering and hardship assumed providential significance, in a journey of atonement and redemption which led Catholics to see themselves as interpreters of His justice. Unlike battles such as Lepanto or Jarnac, sources do not record the singing of the Te Deum on the battlefield: since the Crusades, combatants had given thanks to the Lord in this way, giving rise to a sort of "liturgization" of the battle. However, it is likely that these prayers did in fact take place, given the presence of a general such as the Duke of Anjou, a man of deep and tormented religious feelings who, in the aftermath of the fighting, expressed his intention to build a memorial chapel on the site of the battle. ${ }^{75}$ Certainly, news of the triumph was celebrated throughout France and in Paris, where the royal family attended solemn ceremonies of thanksgiving. ${ }^{76}$ But the principal theater for the political-religious elaboration of the battle of Moncontour was Rome, where the pope was quick to align the events with biblical teachings. The news of the victory was greeted with demonstrations of joy, the ringing of bells, and solemn processions. The entire Curia took part in these celebrations, as did the pope himself. ${ }^{77}$ As after the Jarnac, the twenty-six enemy standards captured by papal soldiers were sent to Rome where, in January 1570, they were dragged through the mud during a triumphal procession and then exhibited in St. Peter's. ${ }^{78}$

Although the final outcome of the war was highly unsatisfactory, ending with the Peace of Saint-Germain - a renewal of the limited religious freedom that had been enjoyed by the Huguenots that enraged Pius v — the deployment of a pontifical force in France did serve to revitalize the role of Rome. The charisma of the Dominican pope helped to kindle the fires of religious hatred in a French context, where events were heading towards the atrocities of Saint Bartholomew's Eve. But meanwhile, discourses based on the desire to exterminate

\footnotetext{
74 Amodei to Borja, Tours, October 8, 1569. ARsi, Gall. 82, ff. 161-62.

75 BAV, Barb. Lat. 4904, f. $167^{\text {rvv }}$. The news was also in an avviso dated October 9. BAV, Urb. Lat.

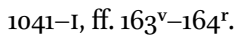

76 Jacques-August de Thou, Mémoires de Condé [...], contenant ce qui s'est passé de plus mémorable en Europe (Paris: Rollin, 1743), 1:410.

77 Avviso from Rome, October 22. BAV, Urb. Lat. 1041-I, f. $167^{\text {r }}$.

78 Avviso, January 7,1570 . BAV, Urb. Lat. 1041-I, ff. $210^{\mathrm{v}}-211^{\mathrm{r}}$. For the processions to celebrate the battles of Jarnac and Moncontour in the context of the papal rituality, see Maria A. Visceglia, La città rituale: Roma e le sue cerimonie in età moderna (Rome: Viella, 2002), 201-27.
} 
the enemy of the faith, the crusading ideal, and the millennial expectations that such tensions awakened had found their most complete realization in the struggle against the Turks. This had led to the Battle of Lepanto, a pivotal event for the Counter-Reformation sensibility. It was precisely in the last Mediterranean crusade that Possevino's model of Il soldato christiano found its full application, thanks to the efforts of the ecclesiastical authorities and papal and Spanish policies. ${ }^{79}$ But even the experience of Lepanto proved ephemeral in terms of the moral reform of the army. The commitment of Jesuits and other chaplains could be fruitful in stimulating devotion among troops, and occasionally served to encourage and justify confessional violence; but it was far less successful in enforcing compliance with the obligations of Tridentine Catholicism and in providing a moral framework helpful to establishing effective military discipline. Soldiers needed not only religious inspiration but prompt and reliable pay, efficient logistical services, constant drill, honest and judicious commands. These were all conditions that European states for a long time would not have been able to provide. When, finally, an army corresponding to the theoretical canons appeared, it was not Catholic but Protestant. Much more than Catholicism, the Calvinist doctrine, with its reference to individual effort, the perseverance in the Gospel and the immediate relationship between religion and state, lent itself to the identification of religious motives with national ones. Conversely, the soldato christiano, postulated by Possevino and promoted by Pius v, involved an appeal to an increasingly anachronistic model and the necessity of a constant ecclesiastical presence like a medium between the concrete activity of the war and the transcendent need for justification and salvation.

79 Gianclaudio Civale, Guerrieri di Cristo: Inquisitori, gesuiti e soldati alla battaglia di Lepanto (Milan: Unicopli, 2009). 